\title{
The Socio-Technical Dynamics of e-Commerce Adoption in the Mainstream Grocery Supermarkets in South Africa
}

\author{
Nhlanhla Mlitwa, Nokuzola M. Raqa \\ Information Technology (IT), Faculty of Informatics \& Design (FID), Cape Peninsula University of Technology (CPUT), Cape \\ Town, South Africa. \\ Email: Mlitwan@cput.ac.za, nokuzola.raqa@allangray.co.za
}

Received May $2^{\text {nd }}, 2012$; revised May $30^{\text {th }}, 2012$; accepted June $17^{\text {th }}, 2012$

\begin{abstract}
The paper is an outcome of a study on the factors of the emerging e-commerce adoption and usage in the mainstream grocery supermarket sector in South Africa. A qualitative, interpretive method using multiple case studies, together with a purposive method of sampling was used. To improve generalisability, more than one leading chain store: Pick'n Pay, and Woolworths were selected as case studies. Individual customers were also interviewed to learn of their experiences with, and preferences of e-commerce in the sector. The activity theory (AT) was used to contextualise e-commerce as a work activity. The theory offers a holistic lens for retailers, banks, customers and even researchers to understand, investigate and approach factors of e-commerce usage. The leading assumptions of a theoretical framework was that ecommerce as an activity system is not an automatic but a deliberate phenomenon that is driven by goals of the retailer and the needs of the customer. Related activities include the presence of facilities among local communities and awareness (marketing) efforts by service providers. Findings suggest that e-commerce offerings by retail supermarkets are not well known by most customers, hence usage is limited. Among the few that use it, it is found to be time-efficient and convenient. Nevertheless, lack of access to e-payment facilities and fear of cyber crime remain a threat to widespread usage. Thus, banks, retail supermarkets and the educational sector need to educate the public on e-commerce and security conscious- ness. Finally, e-commerce facilities should spread beyond boundaries major cities if its conveniences are to be within reach of the majority. Though sample size was adequate for the exploratory purposes of this study, it would have been preferable to interview the whole South African consumer population, an exercise was beyond the capacity of the project, but recommendable for future studies.
\end{abstract}

Keywords: e-Commerce; e-Commerce Awareness; e-Commerce Security; e-Commerce in South Africa; e-Payments in Supermarkets; Online Groceries; Information Society

\section{Introduction}

ICT have revolutionised the way business organizations advertise, market their goods and services, or even conclude purchase and sale transactions with Internet connected customers online [1]. In what is known as e-advertising or "advertising on the web" [2] for example, organisations use online multimedia platforms to display merchandise and services. This way, businesses can reach potential clients in their offices or homes, anytime [2]. In a similar way, Online marketing as the "activity sets of institutions, and processes for creating, communicating, delivering, and exchanging offerings that have value for customers, clients, partners and society at large" [3] or e-marketing, enables companies to have feedback from targeted potential clients faster and efficiently $[1,4,5]$. Even better still, are the possibilities of e-commerce to a networked consumer, where pur- chase and sale of goods and services can be concluded online from anywhere, at anytime [6]. For example, Long Cottage B\&B (www.longcottage.co.za) makes use of pay-per-click advertising on Google, targeting keywords such as "cheap accommodation in Cape Town" to help potential clients to easily find accommodation at Long Cottage B\&B, no matter where they are in the world at the time of search. In the larger business sector, air-flight companies such as Mango (www.mango.co.za), car rental companies such as Tempest

(www.tempestcarhire.co.za) and retail companies such as Woolworths (www.woolworths.co.za) and Pick'n Pay supermarkets in South Africa, have introduced Internet platforms to display and sell their products directly to the public.

E-commerce has grown significantly from where it was a few years back, and has recently penetrated the mainstream retail supermarkets such as Pick'n Pay and 
Woolworths in South Africa (SA) where the majority of customers across various population groups do their daily grocery shopping. The problem however, is that e-commerce has, for a long while been a privilege of the minority that has knowledge and means to use online facilities and its related e-payment resources. The majority that still doesn't have access is by default, excluded. It remains unclear how this innovative benefit is extending to the ordinary customer among the majority of the population across all communities in SA.

This paper reports on an investigation into the dynamics of e-commerce adoption by the mainstream-general household grocery supermarkets in South Africa, from a socio-technical perspective of information systems. Sociotechnical refers to technology (in the form of electronic systems) as a shopping platform, and its social benefit (the general household grocery function) in the knowledge-based society of the 21st century. Knowledge economy and society according to Castells [7], refers to the society that makes full use of technology in all aspects of lives, be it for work or play. The focus was on the awareness of e-commerce offerings, knowledge and ability to use it, access to electronic means of online payments (epayments), trust and confidence in the security of ecommerce, the issues of delivery efficiency and ultimately the general benefits of e-commerce for the consumer.

The context of this work is embedded in the following 4 major concepts:

- Social benefits-In the context of e-commerce, social benefit refers to the value that the capacity to buy the merchandise online-adds to a person's shopping experience. The value in the shopping experience refers to whether e-commerce makes shopping easier, efficient and convenient. Easier in the sense of simplifying procedures of shopping routines, for example instead of having to push a shopping trolley yourself, it is easier when you get the merchandise with doing this yourself. Instead of having to carry groceries to your car, and ultimately load and offload them, it is easier when this is done for you. In short, the shopping experience is simplified (made easy) when it does not require undue physical effort to do the shopping.

- Shopping is efficient if it is accurate (if you ask for a specific item in a specific condition and size, that you get it in exactly that condition), and that the merchandise is obtainable without undue delay and if no extra cost is incurred. Shopping is also convenient if it the shopping transaction can be started and concluded in terms preferable to the purchaser, for example, if one can do shopping at the time of their choice, faster and easier.

- e-commerce-Whilst this term is discussed in detail under the literature background, in short, it refer to the trading of goods or services over the Internet. For purposes of this paper, the business to consumer (B2C) type of e-commerce is discussed.

- Mainstream grocery retail supermarket-Although ecommerce is not new in modern commerce, its adoption by the mainstream grocery retailers is new. The mainstream grocery retail supermarkets refer to the large, everyday and monthly shopping supermarkets that sell food and the general household groceries to customers across economic classes and income groups. Examples in the South African context would include Pick'n Pay, Woolworths, Spar, Shoprite and Checkers.

- Ordinary customer-In this paper, this to families and individual customers across income groups, educational backgrounds, economic classes across all community locations.

The paper opens with a review of literature and a theoretical framework, followed by a research methodology as well as the findings and a conclusion.

\section{Literature Review}

e-commerce is the trading of goods or services over the internet through business to business (B2B), consumer to consumer (C2C) and business to Government (B2G), business to consumer (B2C) among other categories. $\mathrm{B} 2 \mathrm{~B}$ trading can be done internally (within the same company) or externally $[5,8]$ whereby, in the case of KIA motors the servicing department would buy the required car parts from another department within the company. Similarly, C2C is the process whereby individuals sell goods to each other online. B2G trading on the other hand, is when businesses sell goods or services to the government online [9]. B2C, which is the subject of interest in this paper, is the process where businesses sell merchandise online to consumers. Amway

(www.amway.com) for example, sells their products to individuals instead of companies online [5,6]. Information security is an important factor in all forms of ecommerce.

The simplicity and convenience of using e-commerce as a shopping method are illustrated in Figures 1-4. In fact, Figure 1 shows a detailed description of each item that is being purchased (included in ones shopping basket), so that the customer may verify the item they have to what they really intended to buy.

As shown in Figure 2, these shopping items are further shown in a shopping trolley for the customer's verification.

Once again, the customer is afforded an opportunity to the final check, in the form of a check list in Figure 3, so as to satisfy themselves not only that they have the correct items, but also to check if they are not omitting any necessary item in their shopping process. 


\section{Browse Products 8 Advanced Search Delivery Details}

\begin{tabular}{|c|c|c|c|}
\hline Bakery & $\sqrt{\Delta}$ & Bread & Brown Bread \\
\hline $\begin{array}{l}\text { Baking ingredients } \\
\text { Beverages } \\
\text { Butchery } \\
\text { Cheese Bar } \\
\text { Chilled Foods }\end{array}$ & - & $\begin{array}{l}\text { Bread Rolls } \\
\text { Cakes } \\
\text { Tea Time Savoury } \\
\text { Tea Time Sweet }\end{array}$ & $\begin{array}{l}\text { Continental Bread } \\
\text { Health \& Seed Loaves } \\
\text { Pita \& Flat Bread } \\
\text { Rye \& Sour Bread } \\
\text { Savoury Bread }\end{array}$ \\
\hline
\end{tabular}

Bakery pnp Brown Bread 600G 1 EA

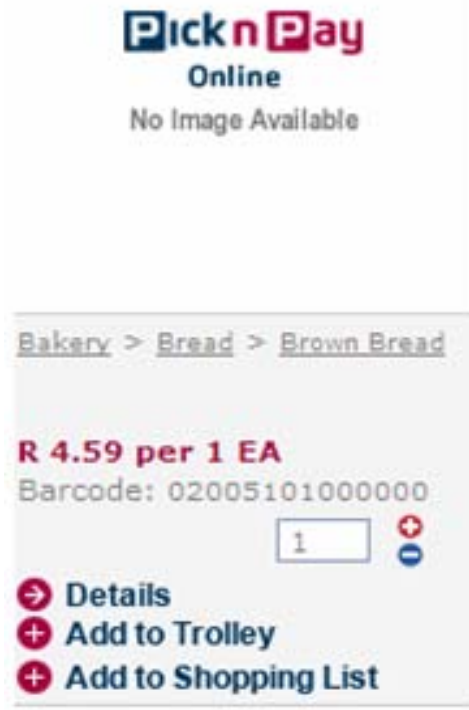

Albany superior Low Gi Sliced Brown Seed Bread 700 GR

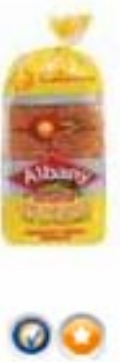

Bakery > Bread > Brown Bread

Was:R-8.99 per 700 GR Now:R 7.99 per 700 GR Barcode: 06001253010352

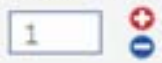

9 Details

$\uparrow$ Add to Trolley

$\oplus$ Add to Shopping List
Albany superior Standard Sliced Brown Bread 700 GR

R 7.39 per 700 GR

Barcode: 06001253010185

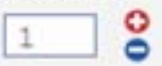

$\rightarrow$ Details

Add to Trolley

Add to Shopping List

| Previous | $1 \leq 1$ Next $\%$

Sort by Default 12 Items Per Page

Figure 1. Online shopping-item description; Source: www.pnponline.co.za.

Obviously, any online purchase is incomplete without ascertaining the delivery process. In this respect, Figure 4 outlines the second last step (before checking out or making payment) towards the conclusion of the purchasing process, which is the booking of the delivery slot.

\section{1. e-Commerce and Security}

According to Weideman [10] companies need the Internet and its related technologies to "have" as well as to use e-commerce. Users worry however, that their confidential data such as credit card details over the network might be exposed to the wrong hands [6]. With adequate security, users develop more trust on the system and can use it frequently, which makes both the physical and logical aspects of computer security a significant part of e-commerce. The physical aspect refers to manual precautions using devises such as alarms, safe and vaults, guards, fire proofs etc. [6]. Most banks have safes and vaults to safeguard their treasured items, making hard for criminals to reach. The logical aspect refers to user authentication (software) applications used to grant various access rights-and to protect assets using non-physical 


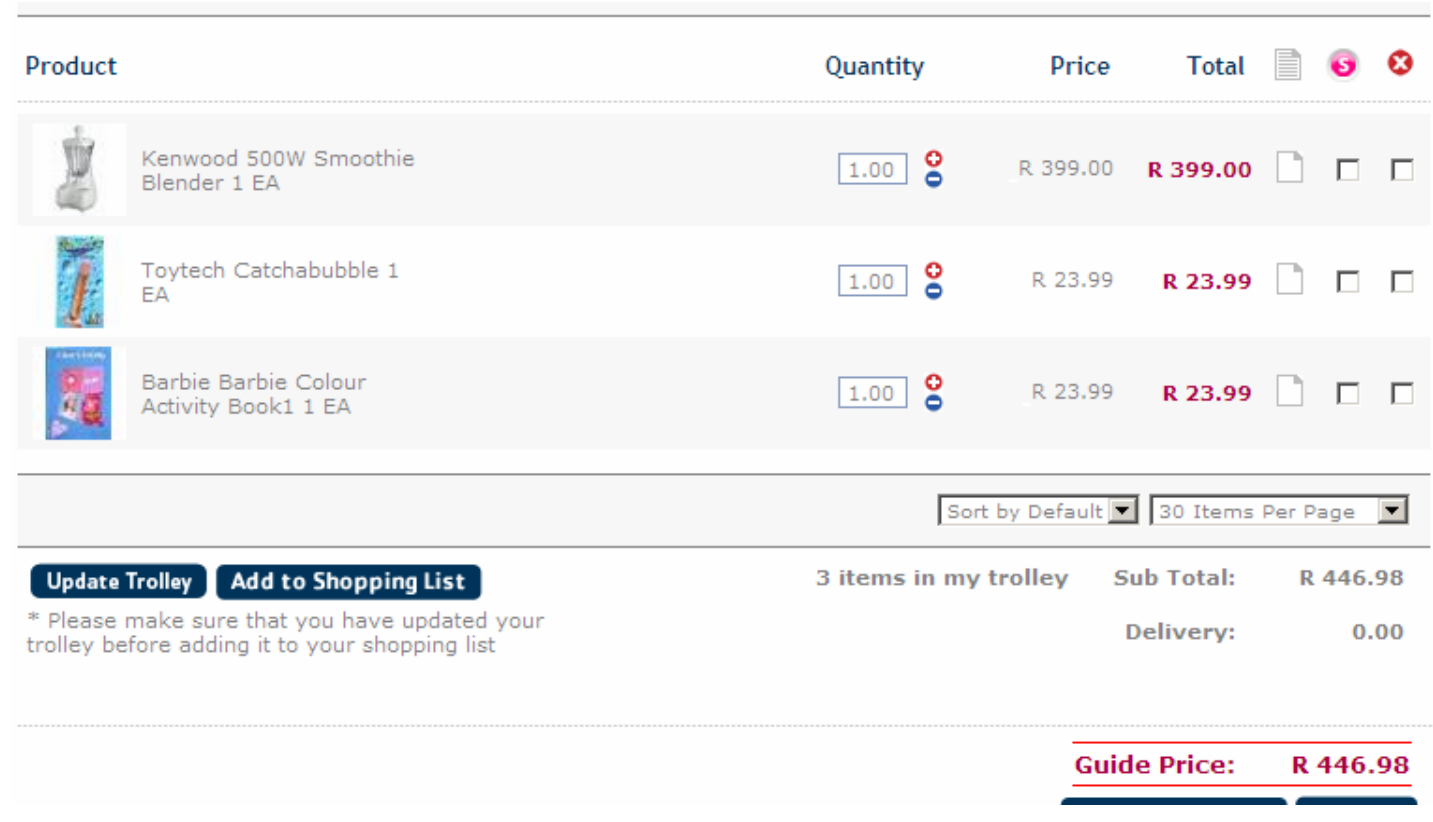

Figure 2. Trolley-Items bought; Source: www.pnponline.co.za.

\section{Checkout}

Home $>$ Check Out

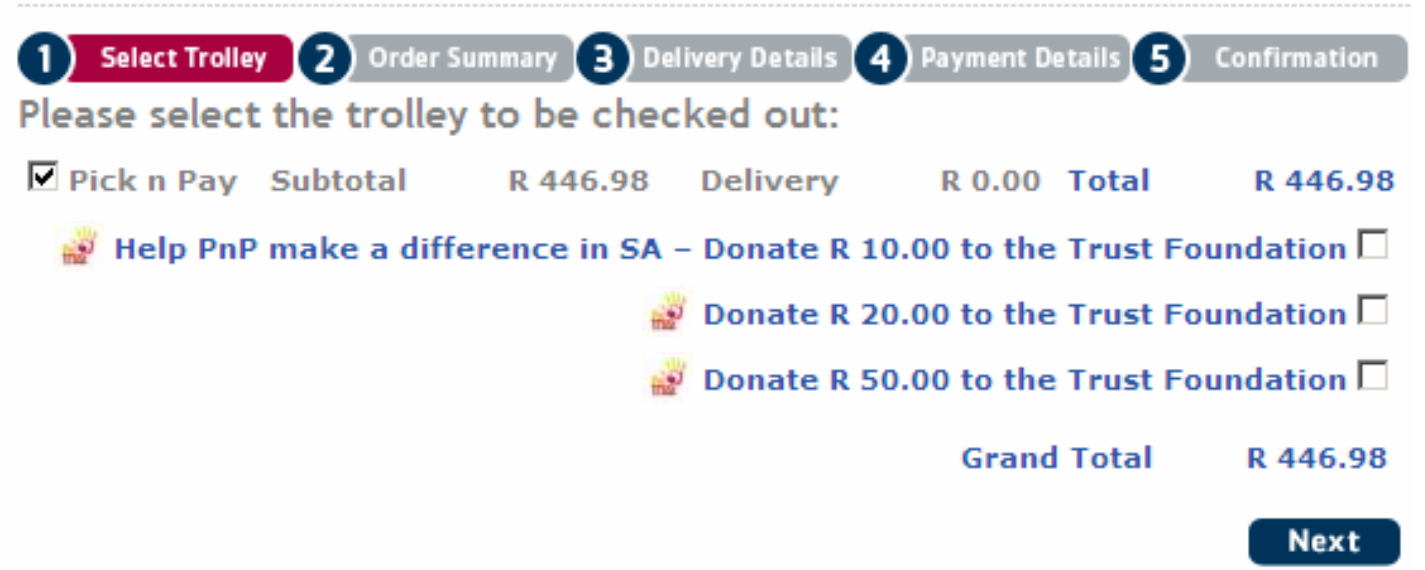

Figure 3. Check list-Items bought; Source: www.pnponline.co.za.

means, including firewalls and virus scanners to avoid hackers or crackers away [6]. Because of the dependence of online-payment systems on software technologies, logical security that requires more awareness, vigilance that ultimately, requires reasonable literacy capabilities for the user, is the most relevant aspect of security in electronic payment transactions.

\section{2. e-Commerce and Methods of Payment (e-Payments)}

As opposed to physical cash or cheque payments methods, e-commerce requires more innovative electronic methods such as e-cheque, the electronic bill presentment and payment (EBPP), Smart card and payment cards (credit card system) amongst others.

\subsection{1. e-Cheque}

E-cheque is a dated and electronically signed online document specifying when the payment can be made [11]. It is offered to account holders by a number of banks to enable online payments, meaning that one needs to have a bank account and access to the Internet in order to use it [12]. Proof of your demographic detail, age, and legal status-by providing Identity document (ID), passport or drivers' license, is required to open a bank account. Proof of address such as a letter sent to where the 


\section{Please select a delivery slot time and day}

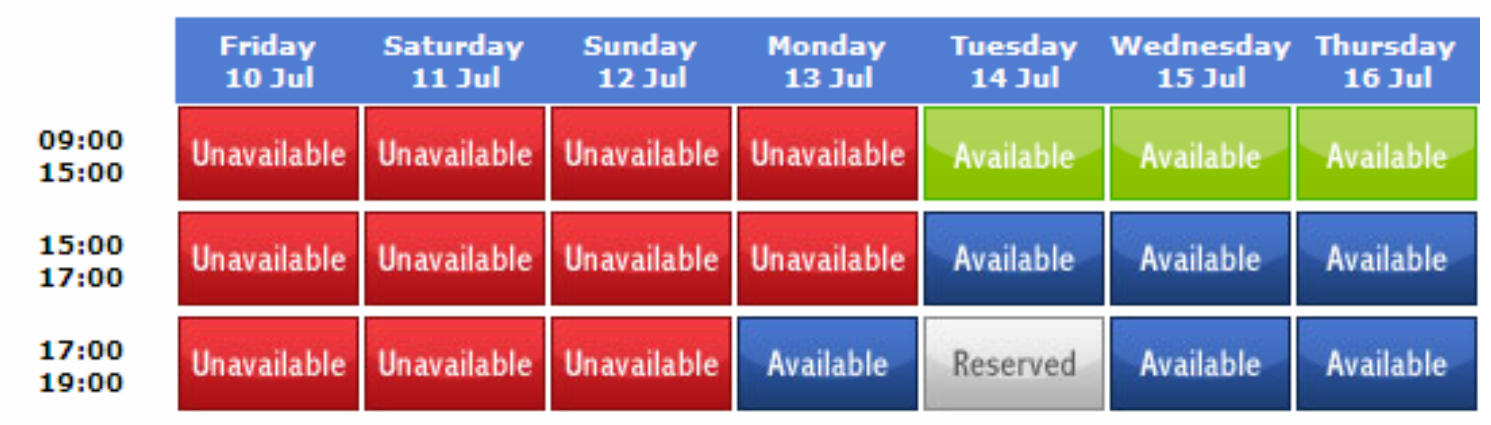

Next Week

Continue

Figure 4. Delivery slots and the customers’ reserved slot; Source: www.pnponline.co.za.

customer resides is also necessary. You also need money to deposit when opening up the bank account [13], and Internet access. E-cheques differ from normal cheques in that instead multiple signatures and paper documents, they are soft cryptographically signed documents requested, registered and transmitted over the Internet [11].

To use an e-cheque, the credentials get verified and the user receives access right in the form of a username and password. The user then logs into the account and verifies his/her details. The issuers' the bank validates the transaction and sends confirmation to the billers' bank for settlement [11]. Like any other method, e-cheque has its advantages and disadvantages. Unlike in the normal cheques, the signatures in an e-cheque are verified instantly, which makes an e-cheque more secure. Since echeques are designed with the message integrity authentication and non repudiation properties banks and customers are more protected against fraud, which makes it easier for users to trust [11]. Secondly, it is convenient in that one does not have to travel to their client or the bank but usable from any Internet connection point (be it at home or work). The Payee Identification feature to uniquely identify the payee further improves the security of e-cheques. Duplication detection further guarantees the uniqueness of each e-cheque and the process is asynchronous, which makes it less susceptible to network disturbances [14].

The use of e-cheques, thus, would naturally require a confident level of numerical and technological literacy. In addition, that e-cheque transactions are costly [14] could be a concern for the economically disadvantaged majority. The Electronic Bill Presentation and Payment method is another alternative for payments of online purchases.

\subsubsection{Electronic Bill Presentation and Payment (EBPP)}

This is a process of collecting customers' bill processed by different companies for electronic payment over Internet and wireless devices, etc. [15]. To use it, the customer gets the bill traditionally or electronically, and should it be an electronic bill, the customer logs into the EBPP website to review it [15]. The customer can instruct their EBPP provider to make the payment. The advantage is that it is possible to schedule a payment up to a year in advance or schedule recurring payments. Billers can also update their bills constantly, making it easier for consumers to get the latest bills faster.

EBPP is vital benefit to the financial, telecommunications and utilities institutions that need to process client bills online [16]. It is also advantageous to "biller-direct" sectors where payments are done directly to the companies providing the customers with goods or services [17].

Like the e-cheque however, interested users need to have a bank account and Internet access [13]. This method of payment is unfortunately, costly and lacks consistent functional reliability as it does not always produce customer bills every time when required [16]. Unlike echeque transactions where you can make payments for purchases made [11], EBPPs are used to settle existing bills. Because of its high cost and reliance on Internet connectivity it has largely been the privilege of the minority with Internet access. Even amongst this privileged group, the cost is a discouraging factor [15].

Though not common, smart cards are also used in other parts of the world to pay for online purchases.

\subsubsection{Smart Card}

Smart Cards are plastic cards with chips used as micro- 
controllers. They have a unique ability to carry out their intended functions. For example, digital signatures interact with a Smart Card reader, making relevant decisions through the process of paying for financial transactions by sending the request to the card reader. Once this is done the transaction is approved or disapproved [18]. The physical device and a password are required to use the Smart Card, which helps prevent hackers from using someone else's account by just having the password [6].

In addition, banking applications with credit and debit functions are supported by the smart card [6], even though it is not advisable for one card to make use of multiple applications as it might compromise the security of the client's data. To avoid data overwriting, it is advisable that one card should make use of one application as the system could easily be vulnerable to fraud [6], but since the chances of copying a private key on a smart card are few, the security level is very high. This makes it very expensive and almost impossible for everyone to access and use it [19], and further, merchants hardly make provisions for the use of this facility in their online shopping systems. Since it is expensive and hardly catered for in common online shopping systems most people use the payment cards for online transactions.

\subsubsection{The Payment Cards (Credit Card System)}

Payment cards are debit, charge and credit cards. A debit card is "a convenient and safe payment approach whereby funds will be deducted, or rather, 'debited' immediately from your savings or cheque accounts when pur- chasing or paying for goods or services” [20]. While a charge card requires customers to pay their balance in full upon receiving the statement and without interest charges, the banks are very strict in granting it. They do a full credit history to analyse the customer spending habits and to assess how much they can repay, before approving them, and only for the amount a client can afford to repay [21].

A credit card on the other hand, is used to purchase and pay off or online, using funds that can be paid at a later stage with interest [22]. A case of an online flight payment method using a Visa credit card is demonstrated in Figure 5.

To get a credit card in South Africa you need to meet certain bank requirements. You need to be over 18 if married or 21 if single. Like the e-cheques and EBPP, you need to have a bank account, a South African ID or a passport [23], fixed income [24] and good credit record [25]. These pre-requisites help banks ensure that customers can repay their debts.

The advantages are that they can be used worldwide. Unlike other cards, a credit card allows customers the benefit of using an overdraft [7]. The bank also limits the amount they give the applicant to what they think the customer can afford [23].

However, any balance on the credit card is charged with interest $[7,25]$. Whilst credit card advances are useful, most people start seeing them as extra money, with a temptation to overspend [26]. As most companies around South Africa cater for this method of payment it has

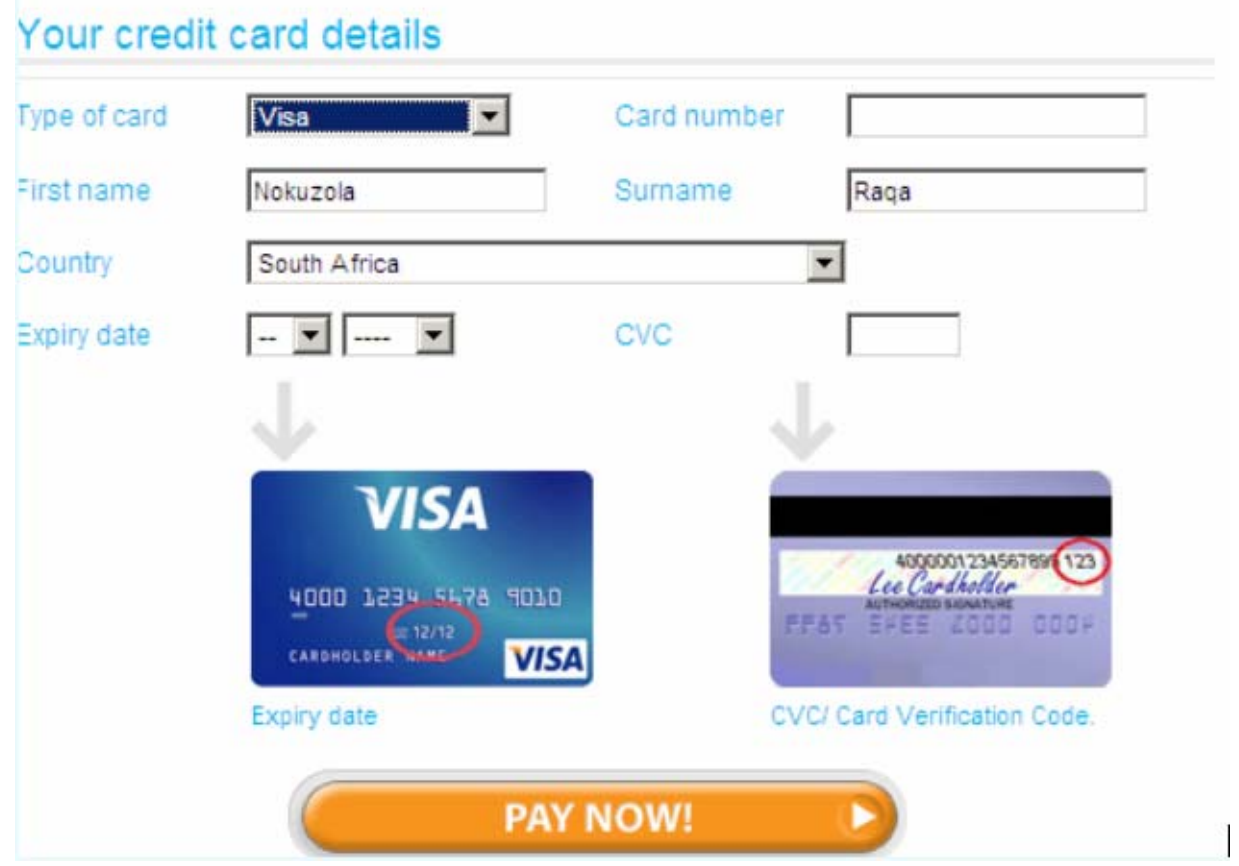

Figure 5. Mango Airline's payment method; Source: www3.travelstart.co.za/cartItinerary.jsp?extPartner=\&payTime= Pre\& priceOrder=1\&cartId=4341857_EEC6D9\&random=12000. 
become the most popular one, with many merchants like Mango airline, Woolworths, Truworths and Pick'n Pay only catering for the credit card payment option in their online systems.

Despite the popularity of credit cards, not everyone has or is able to get it, which implies an apparent limitation to e-commerce usage.

\section{Theoretical Framework}

As informed by Engeström [27], the activity theory (AT) is built on Vygotsky's [28] concepts of mediated action, where an activity is more than just a function of internal biological processes, but socially mediated-by culture, artefacts (including signs and tools) and context [29]. The AT is built on several key concepts: actors, actions, mediation, subject, object (goal \& motives), tools, transformation (process), rules, community, division of labour, and outcome. Both the activity and context feature strongly in the vocabulary of the activity theory [30]. An activity is seen as a factor that ties individual actions to the context, hence a basic unit of analysis in Activity Theory [31]. Since human actions derive their meaning from the context, "actions without context are meaningless" [32, p. 6], hence actions are to be viewed within a context. The AT work-activity concepts are used to present e-commerce as an activity system in Figure 6.

Figure 6 builds on the activity theory to present ecommerce work-activity (the activity of buying and selling online). The work activity thus, involves actors, goals, activities, mediators, transformation as well as the outcome. Information flows and linkages between the five components of the activity system are important in the success of the work-activity.

At the institutional level, the actors are the merchant (grocery supermarket), the bank as e-payment service provider, the sales persons and network administrators in the store, and ultimately the customer. A customer in this case is anyone who approaches the store to conclude a purchase and sale transaction. The work-activity approach emphasizes the significance goal pursuit in work activities. Figure 6 shows two significant goals in the e-commerce work activity. The goal of the merchant (organization) is to improve competitiveness, increase market share and profitability through customer satisfaction. In this process, network administrators aim to ensure continuous network efficiency so that online purchase and sales may continue, and ultimately help towards the realization of overall company goal. Similarly, the sales team aim to satisfy customers through efficient (fast, friendly, accurate and cost efficient) sales.

The customer on the other hand, wants to buy a specific product to meet his/her need. The customer needs a product in a specific form, condition and quality, cheaper and in time. An online shopping environment is thus, used by most customers.

A realization of the goals of the merchant (supermarket entity) and those of the customer however, depend on the mediating factors. Positive mediators for the merchant imply the presence of enabling conditions such as a working system, a fast and secure network, availability of electronic payment facilities, efficient sales team, availability of merchandise, willing buyers, and the usability of the system for online purchase and sales. On the customer side, awareness of e-commerce offering determines whether they use it or not. Secondly, system safety, ease of use and flexible availability enables usage. Delivery efficiency and the experience of first usage, obviously informs future decisions. This framework is used to contextualize interview transcripts in findings section.

Methods of investigation are outlined under research methodology section below.

\section{Research Methodology}

A choice is made between positivist (using mostly quantitative methods associated with natural sciences), quailtative, critical and interpretive approaches [33] in information systems research. The positivist research tradition holds that there is only one way to conduct research observations and measurements. That is, the researcher, the subject and the context are treated as separate phenomena that can only be observed independently. Secondly, that the only way to find the truth is by observing and measuring objects separately from the researcher and the context [34]. Given the significance of understanding the subjects and their contexts in this study, the positivist approach could not fit the purpose. The qualitative approach (which incorporates both the critical and interpretive paradigms) on the other hand, includes methods such as action research, ethnography and case studies, using data collection techniques such as the observation of documents and texts, participant observation, depth interviews and focus group interviews with or without questionnaires [27].

Whilst the critical approach is concerned with understanding conflicting structures such as political, economic, cultural, gender and ethnic tensions [35] in sociotechnical investigations [36], the interpretive paradigm sees a socio-technical reality to be embedded in technical and social contexts. It assumes that reality is not objectively determined, but socially constructed [37]. As such, socio-technical phenomena cannot be adequately understood separately from their social environments and contexts.

The focus of this study was on understanding interpreting the value of e-commerce shopping tools (technology) and processes (social actions), and the dynamics of its adoption and use among customers (humans) as 


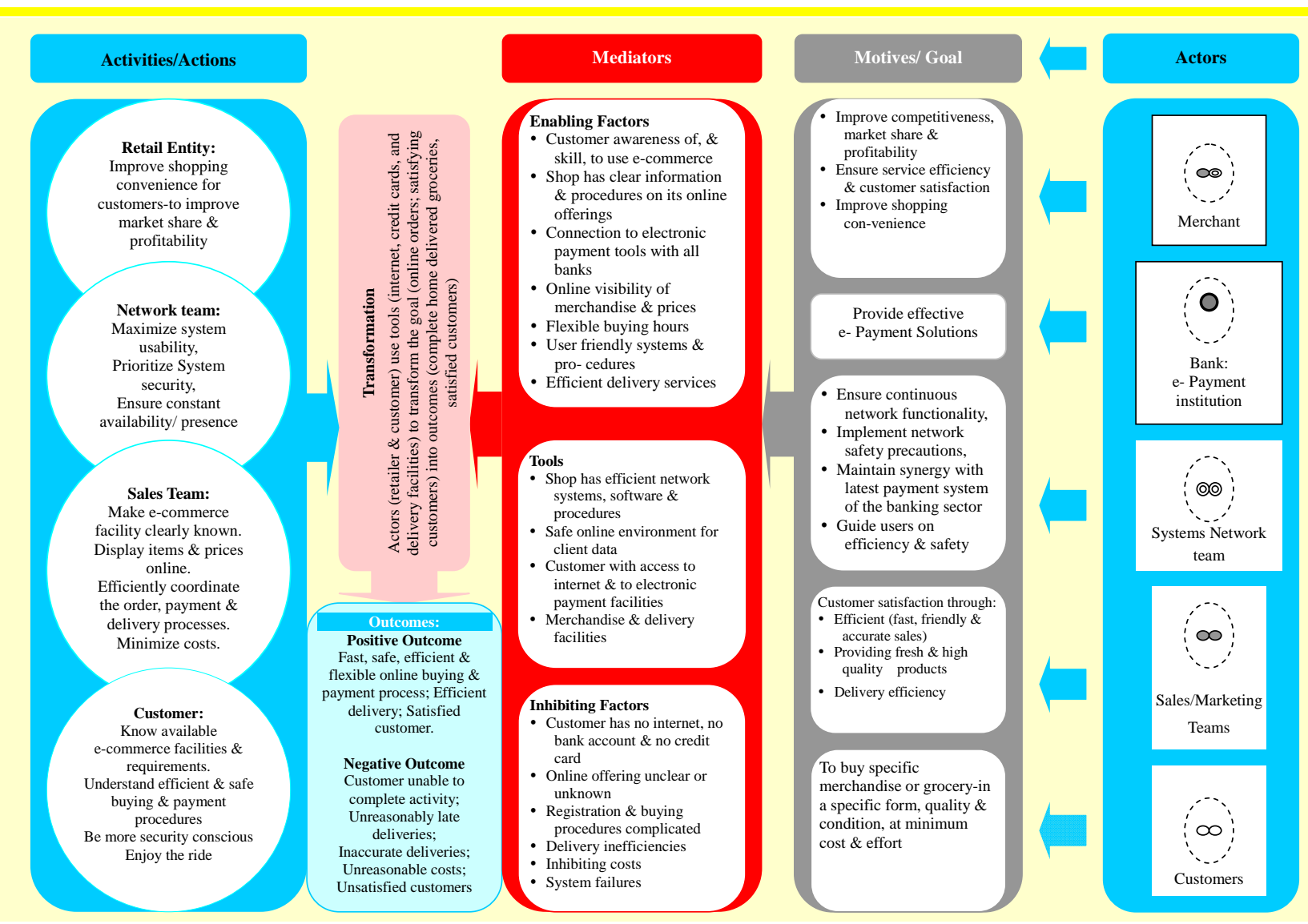

Figure 6. e-commerce process as an activity system.

they interpret it (interpretations). The interpretive method using multiple case studies thus, became a logical option.

Case study methods are used to understand, describe and explain a certain phenomenon in its real life contextin detail, using one or more representative sample [38]. To improve generalisability, this study uses more than one institution: Pick'n Pay, and Woolworths as case studies, together with interviews of individual customers to learn of their experiences with, and preference of ecommerce in the mainstream grocery retail sector. Purposive method of sampling was used to select respondents.

Purposive sampling is used to select a small representtative subset [32] of a larger research population-from which generalisations can be made [27]. A researcher only approaches members of a research population that that are most likely and willing to supply information about the rest of the population studied [39]. Guided by the objective of the study, Woolworths (website content) and Pick'n Pay (central marketing manager) were selected as representative cases of the grocery supermarkets. A total of seven customers were also selected for observation. Among the customers-two (2) knew nothing about e-commerce, three (3) know e-commerce but had never heard of it in retail supermarkets, and two (2) know and had used online grocery shopping in retail supermarkets. Interview techniques and ultimately, interview transcripts were used as data collection and recording tools. The activity theory was also used to develop a theoretical framework as a lens to understanding the socio-technical factors of e-commerce adoption and usage, generally.

\section{Findings}

Though online trading is no longer a new phenomenon, it is relatively new (under five years as of 2009) in the mainstream household-grocery sector in South Africa, hence it is still unclear how users understand and use it.

Interview respondents were asked to indicate their understanding of e-commerce.

Findings: As much as e-commerce is a convenient way to do shopping, findings show that it is still not fully known and used by many customers. The understanding of e-commerce varies from those who have never heard of it, to some who have a conceptual knowledge without practical experience, and those with both its conceptual and practical knowledge.

Out of the seven customer participants for example, 
two respondents did not know what it is, nor have they ever heard of it: "No, I've never heard of it" [40,41]. They were however, very keen on using it thereafter, and were hoping they could learn more about it. They were also hoping that it could be marketed to them so that they could be better exposed to it. In the words of one respondent, "...handing out pamphlets in shopping malls" would be useful. "For instance when you go buy at the shop, there should be some pamphlets available, or TV and radio adverts" [42]. This will be difficult because some companies do not believe in marketing their online shopping. For example the marketing manager said "for the last 3 or 4 yrs, Pick $n$ Pay has done zero marketing" [43] of its e-commerce offering. With this approach in other supermarkets, it may still take a while for the majority to learn of, and begin to use e-commerce for their household groceries.

Respondents that indicated knowledge of e-commerce were also asked to reflect their conceptual understanding of e-commerce.

Findings: Although respondents do not use exactly the same words in defining e-commerce, conceptual agreement of its meaning is evident in their assertions. Various sets of interpretations by six interviewees seem to converge around the terms of "transacting" [44], "to do Commercial transactions" [45] or "conduct businesses" [46] and "buying products" [41,43] or "goods easy" [42] "online” [42-45] Whilst some respondents refer to merchandise either as products, goods and simply refer to the processes as buying or transacting, all respondents agree on the "online" platform on which the process is concluded. The "online" platform and its related processes therefore, is central to the concept of e-Commerce.

To understand usage dynamics, respondents that understand e-commerce were asked to indicate whether they are using it, and ultimately the benefits.

Findings: Even though five interviewees knew about e-commerce only a few had used it, only two had used it to buy general household groceries in retail supermarkets. They found it very useful in their busy lives. It saved them time, allowing them to attend to other activities, which gives them more time with their families instead of spending half of the day looking for the required items in shops. In addition, customers get to stick to their budget and not end up buying items they do not need or go to other shops while they had not planned on doing that. One respondent states for example, that "if you're in the shop yourself you like, I tend to overspend. You buy stuff you don't need or go to the shop next door you spend more money", "while you edit your list online you tick all the time outs and at the bottom of the screen it will actually say the amount already so when you add it will increase. So you can say exactly how much, and the total is, so if you, you're in a tight budget it's easy when it's online shopping" [43].

Respondents were also asked to indicate userfriendliness in terms of the ease of user of online paying systems for major grocery retail supermarkets they had used.

Findings: Regardless of the ease and convenience, some people believe in using them selectively, to buy certain goods and only in selected times. For example one interviewee only “...use it for monthly grocery shopping” [43] and not the daily items.

The user however, finds "it's very easy, you just register, you put your address details in, and then they give you a whole list of products to choose from. You tick and off the list and then you choose the delivery date and time and that's it" [43]. You "click online, select your product, put it into your shopping basket, at the end view your shopping basket, check that everything's there and then you click send" [47] and the respondents know all the steps.

Some find it beneficial as it improves their shopping experience, citing the ability to shop all alone without having people around as the advantage. The reason according to Alexander [46] is that shopping centres "...tend to get very full and you get irritated and frustrated because everyone is around there. Online, it is comfort of your own house".

Users were also asked to indicate their concerns.

Findings: There are a few difficulties associated with shopping online however. For the already cooked food, it would be cold by the time it gets to the customer "Only thing is for warm stuff, cooked stuff sometimes it comes not too warm, cold" [44] and you have to be home at the chosen time of delivery, else you end up inconveniencing the deliverers. If “...they say they're gonna deliver 5pm, be at home they will deliver at 5pm [43]. The customers still do not mind and use the option. Here are some difficulties on the side of the supermarkets too. For example, should there be traffic on the way to the customers' place the driver can get stuck which makes “...traffic a big problem" [48]. Because of this most supermarkets "trucks are fitted with GPS" [47] so that the driver can find other alternate routes to get to their destination. As much as it is easy to use, however, only those with access to the Internet and payment cards can use it. To be able to use it, says one respondent-you need "your credit card, your credit ratings and money in your bank" [46].

As the activity framework suggests, e-commerce is a convenience, but also a rational process, and there are customers who do not believe it is for them. "For me", says one respondent "it's the physical because I think the touch and feel, there's that works for me" that is important [44]. Some believe shopping online will not be as fun as physically going to the shop. For Yang [45], "gro- 
cery shopping is not just about picking the items. It's also about pushing the trolley and enjoying the experience". They believe it is fine to shop for other things like DVD's as long as it is not food. Yang [45] for example, does not "...see the benefits of shopping groceries online compared to buying something like DVD's or books". So, it would be short-sighted to see e-commerce as a panacea and a once-size-fits all solution societal shopping needs, but a worthwhile alternative.

Finally, user-respondents were asked about their awareness and concerns of the security aspects of ecommerce.

Findings: Some believe it is safer to shop online than going personally to the shop. For example one interviewee believes "going to the shop in person" [43] is "...more dangerous" [43] and she would rather do her monthly groceries online as it "is very secure" [43]. In agreement, another interviewee adds that as long as the "right mechanism is put in place by the shop" [45], e-commerce should be secured, with Yang [45] adding further that the customers need to take precautions by using their "common sense" and "avoid using public computers to shop online; have anti-virus and Internet security software installed and kept up-to-date and not clicking on unknown links" [45]. This way, it does not only become the shops' responsibility to protect the customer.

Another interviewee is concerned about "credit card fraud" [46] but still believes in shopping online, she says the person just has to be careful and "pray and hope that there are decent and honest persons out there" [46], whilst the other says by shopping online you increases the chances of your "your ID/PIN details" [44] being used by the "hackers" [44]. None of the respondents know what they would do if they could become victims of crime, nevertheless, most customers do know about the security risks associated with shopping online but do take their chances as it is convenient for them. Awareness on security conscious thus, is an important consideration for further e-commerce initiatives by banks, merchants and training institutions.

\section{Analysis}

The actors in terms of the work activity framework (Figure 6), perform activities to achieve their goals. The customer needs to buy merchandise in a specific condition and quality, conveniently and cost effectively. To do this, the customer needs to know existing e-commerce offerings and available services, and the practical knowledge to use the online shopping system. In addition, the customer must have Internet access, e-payment facilities, knowledge of shopping procedures in respective online markets, and a need to do shopping (conveniently and cost-effectively). An online purchasing system, with its e-payment tools is thus used to achieve this objective.

On the other hand, the merchant's goal is to satisfy customer needs by providing an effective online shopping environment, and effective delivery of goods.

The mediating factors however, determine the success or failure for the actor to achieve the goal. Knowledge, access to tools (internet, e-payment facilities, and effective merchant online shopping facility), location within catered-for areas, availability of delivery systems, and availability of required merchandise would enable (mediate) successful online shopping by the customer. The converse is thus implied. The merchant also needs a functional network, an efficient system and coordinated processes between the network and sales teams, as well as effective delivery process to enable (mediate) online shopping from their side.

The findings suggest that many people still do not know the meaning of commerce. Most people understand the existence of e-commerce, but have not heard of online shopping facilities in the retail sector. Lack of knowledge for this group thus, becomes a negative mediator (or inhibiting factor). The facility, according to a Pick ' $n$ Pay respondent, is only offered in bigger cities. No effort is made to market the online shopping at Pick'n Pay, hence knowledge only spreads through the word of mouth.

There is a number of people who understand the phenomenon, and had used it to do their online groceries. With respect to the mediators, these customers are empowered by their knowledge of the system, their access to the Internet, their access to e-payment facilities such as credit cards, and ultimately, their geographical location within catered-for areas, and the availability of online shopping options. The online shopping facility is seen as a very convenient and useful option to do monthly groceries. Though a standard fee (R60, at Pick'n Pay and R50 at Woolworths as of July 2009) is charged for any amount of purchase, customers believe the convenience outweighs the cost, though they would rather use the facility to buy monthly groceries to be cost effective [49]. The ever-present possibility of cybercrime was raised as a concern though no practical negative experience reported.

\section{Conclusions}

The study was motivated the growth of e-commerce in mainstream grocery supermarkets in South Africa, with a concern about its only to the minority that has the knowhow and the means to use it.

The activity theory, and the resultant theoretical framework in particular, was useful in offering a holistic approach and lenses to look into the phenomenon of 
e-commerce, from the activity system perspective. The activity framework suggests that e-commerce is a convenience, but also a rational process that is mainly goaldirected (rather than accidental). Knowledge and access to its facilities, the willingness to buy, ease of use of the system, being located in a right area (area that is cateredfor by the merchant), as well as the effective delivery facilities may enable or hinder the process. Though access to credit cards was not raised as a concern, people without access to e-payment tools are excluded by default. Knowledge of e-commerce remains the main hindrance to its access and usage for the majority in major cities, and is beyond the reach of the majority in rural areas outside major cities because they are still neglected by most merchants.

Online shopping in the mainstream retail grocery sector is seen by the users as a very convenient and useful to conduct monthly grocery shopping. When used safely and wisely, it has a high potential to simplify shopping processes for the majority, should they have access and ability to use it. To this end, it is strongly recommended that the knowledge gap among consumers be bridged. For this purpose, a need emerges for partnerships between banks as e-payment service providers, retail supermarkets, and training institutions to educate the public about e-commerce. The educational sector has a significant role to play on e-commerce literacy and security consciousness in this respect. It is also recommended for e-commerce facilities to be spread beyond just the major retail supermarkets, and beyond major city boundaries if its conveniences are to be within reach of the majority. The work-activity framework in this paper offers a holistic approach to view this facility, both from the consumer, retailer, researchers and educator perspectives.

Though sample was adequate for an exploratory study, it would have been preferable to interview the whole of the consumer population in rural and sub-urban areas of South Africa, an exercise that was beyond the capacity of the project. It is nevertheless, an insightful basis for expanded investigations on the phenomenon in future studies.

\section{REFERENCES}

[1] V. Vrana and C. Zafiropoulos, “Tourism Agents' Attitudes on Internet Adoption: An Analysis from Greece,” International Journal of Contemporary Hospitality Management, Vol. 18, No. 7, 2006, pp. 601-608.

[2] K. Haegele, "E-Advertising and E-Marketing Online Opportunities,” The Rosen Publishing Group, New York, 1999.

[3] American Marketing Association (AMA), “Online: About AMA,” 20 July 2009.

http://www.marketingpower.com/AboutAMA/Pages/Defi nitionofMarketing.aspx
[4] P. R. Smith, "Great Answers to Tough Marketing Questions,” 2nd Edition, British Library Cataloguing in Publication Data, London, 2003.

[5] P. R. Smith and D. Chaffey, "E-Marketing Excellence: The Heart of The Business,” 2002, ISBN 0-7506-5335-3

[6] M. Greenstein and M. Vasarhelyi, "Electronic Commerce: Security Risk Management and Control," 2nd Edition, McGraw-Hill/Irwin, New York, 2002, ISBN 0-07-241081-7

[7] M. Castells, "The Rise of the Network Society: The Information Age, Economy, Society and Culture,” Blackwell Publishers, Oxford, 1996.

[8] G. P. Schneider, "Electronic Commerce: The Second Wave, Division of Thomson Learning," Massachusetts, Boston, 2004, ISBN 0-619-21331-0.

[9] R. Tassabehji, “Applying E-Commerce in Business,” Sage Publications Ltd., London, 2003.

[10] Weideman, et al., "ICT Research Forum No.2-200C: Project IV 2005, ICT Research Forum,” Cape Peninsula University of Technology, Cape Town, 2005.

[11] N. N. Murthy, B. M. Mehtre, K. P. R. Rao, G. S. R. Ramam, P. K. B. Harigopal and K. S. Babu, "Technologies for E-Commerce: An Overview," Informatica National Serminar on e-Commerce, Hyderabad, 2001.

[12] S. P. Buck, "Electronic Commerce: Would, Could and Should You Use Current Internet Payment Mechanisms," Consultant, Hyperion Systems Ltd, Guildford, 20 June 2009.

http://www.emeraldinsight.com/Insight/ViewContentServ let?Filename=Published/EmeraldFullTextArticle/Articles/ 1720060201.html

[13] Wisegeek, “What Do I Need to Open a Bank Account?” 20 June 2009.

http://www.wisegeek.com/what-do-i-need-to-open-a-bank -account.htm

[14] W. De Bruijn, “Towards Reliable Backup on the Net by Combining Markets, Swarming and Erasure Codes,” Vrije Universiteit, Amterdam, 2005.

http://www.few.vu.nl/ wdb/publications/asci_distsys_20 05.pdf

[15] A. H. Spiotto, "Electronic Bill Payment and Presentment: A Primier, ESP-2001-5,” Federal Reserve Bank of Chicago, Chicago, 2001.

[16] A. Andreeff, L. C. Binmoeller, E. M. Boboch, T. Ciesielski and E. Green, "Electronic Bill Presentment and Payment: Is It Just a Click Away?” Federal Reserve Bank of Chicago, Chicago, 2001,

[17] IT Now, “Technical Briefing: EBPP,” British Computer Society, 20 June 2009.

http://itnow.oxfordjournals.org/cgi/pdf_extract/49/6/27?rs $\mathrm{s}=1$

[18] The Smart Card Alliance, "HIPAA Compliance and Smart Cards: Solution to Privacy and Security Requirements 2003, ID-03004,” Princeton Junction, New York, 15 December 2012.

http://www.smartcardalliance.org/resources/lib/HIPAA_a nd_Smart_Cards_Report.pdf

[19] D. Chadwick, "Smart Cards Aren't Always the Smart Choice, Internet Watch,” University of Salford, Salford, 
1999.

http:// www.cs.kent.ac.uk/pubs/1999/2116/content.pdf

[20] Absa Bank, 20 July 2009. http://www.absa.co.za/absacoza/content.jsp?/Home/Perso nal/How-Do-I/Manage-My-Payments/Cards/Debit

[21] Investopedia, “Home Page,” 20 June 2009. http://www.investopedia.com/terms/c/chargecard.asp

[22] Credit Magic, “Glossary of Terms,” 20 July 2009. http:// at www.creditmagic.org/glossary/

[23] Nedbank, "Personal Card Application Form-NCA [Nedbank]," 20 June 2009.

http://www.nedbank.co.za/website/content/forms/form.as p? formsid=326\&FormLocation=Nedbank

[24] Sondra, et al., "How to Get a Credit Card when You Have a Low Income,” 20 June 2009. http://www.wikihow.com/Get-a-Credit-Card-when-YouHave-a-Low-Income

[25] Ezine Articles, "Meeting Credit Card Requirements," 20 June 2009.

http://ezinearticles.com/?Meeting-Credit-Card-Requireme nts\&id=909076

[26] Money Instructor, "5 Reasons Why You May Want to Consolidate Your Credit Card Debt,” 20 June 2009. http://www.moneyinstructor.com

[27] Y. Engestrom, "Learning by Expanding,” Orienta-Konsultit, Helsinki, 1987.

[28] L. S. Vygotsky, "Mind in Society: Development of Higher Psychological Process,” Harvard University Press, Cambridge, 1978.

[29] A. N. Leont'ev, “Activity, Consciousness, and Personality,” Englewood Cliffs, Prentice Hall, 1978.

[30] A. Mursu, I. Luukkonen, M. Toivanen and M. Korpela, "Activity Theory in Information Systems Research and Practice: Theoretical Underpinnings for an Information Systems Development Model," Koupio University, Kuopio, 17 May 2009. http://informationr.net/ir/123/paper311.html

[31] N. W. B. Mlitwa and N. M. Raqa, "Information Tech- nology BTech Research Advances,” CPUT, Cape Town 2009.

[32] R. A. Singleton Jr. and B. C. Straits, “Approaches to Social Research,” 4th Edition, Oxford University Press, New York, 2005.

[33] E. Babbie and J. Mouton, "The Practice of Social Research,” Oxford University Press, Cape Town, 2004.

[34] S. E. Krauss, "Research Paradigms and Meaning Making: A Primer,” Universiti Putra, Selangor, 20 June 2009. http://ace.upm.edu.my/ lateef/Handouts\%20-\%20dce\%2 05020/researchparadigmsarticle.pdf

[35] K. Maree, "First Steps in Research,” Van Schaik, Hatfield, 2007.

[36] N. Mlitwa, "Investigation of Integration and Use of ICT for Teaching and Learning in South African Higher Education Institutions," Ph.D. Thesis, University of Cape Town, Cape Town, 2009.

[37] E. Husserl, "Philosophy as Rigorous Science in Quentin Lauer, Trans., Phenomenology and the Crisis of Philisophy,” Harper Torchbook, New York, 1965.

[38] R. K. Yin, “Case Study Research: Design and Methods," Sage, London, 1994.

[39] R. Kumar, "Research Methodology-A Step-by-Step Guide for Beginners," 2nd Edition, SAGE Publications Inc., London, 2005.

[40] Maseleni, “Interview Respondent,” 2009.

[41] Mhletywa, "Interview Respondent,” 2009.

[42] Booi, “Interview Respondent,” 2009.

[43] Brits, “Interview Respondent,” 2009.

[44] Groenewald, “Interview Respondent,” 2009.

[45] Mabapa, “Interview Respondent,” 2009.

[46] Yang, “Interview Respondent,” 2009.

[47] Alexander, “Interview Respondent,” 2009.

[48] Brits, “Interview Respondent,” 2009.

[49] Woolworths, “Home Page,” 20 June 2009. http://www.woolworths.co.za 